\title{
sciendo
}

\section{IMPACT OF THE DURATION OF LARVAL YOLK SAC ABSORPTION ON THE DEVELOP- MENT OF RAINBOW TROUT Oncorhynchus mykiss (WALBAUM 1792) FRY}

\author{
Antonia Kurtela
}

University od Dubrovnik, Institute for Marine and Coastal Research, Ul. branitelja Dubrovnika 29, 20000, Dubrovnik

*Corresponding Author: antonia.kurtela@unidu.hr

\section{ARTICLE INFO}

Received: 7 December 2020

Accepted: 26 February 2021

\section{Keywords:}

Fish

Rainbow trout

Weight

SGRw
Growth rate

\section{ABSTRACT}

Rainbow trout Oncorhynchus mykiss (Walbaum 1792) larvae that first started active feeding were separated into 3 replicate batches $(1 A, 1 B, 1 C)$ with 100 individuals each, while four days later, the fry that last started active feeding were also distributed in 3 replicate batches $(2 \mathrm{~A}, 2 \mathrm{~B}, 2 \mathrm{C})$ with 100 individuals. Four measurements were performed with an interval of four days between the first and second measurements, as well as between the third and fourth measurements, to compare the initial masses of individuals by groups ( $1 A B C$ and $2 A B C)$ on the same day from the beginning of active feeding. The average initial body weight of the fry per batch in each measurement was generally higher in the first group (1ABC) than in the second group $(2 A B C)$. However, when comparing the weight of both groups for the same number of days from the beginning of active feeding, it is noticed that the second group $(2 A B C)$ has a higher average individual weight than the first group $(1 A B C)$. There was no statistically significant difference (one-way ANOVA, p>0.05) in SGRw between the groups in the first three measurements, while there is a statistically significant difference (one-way ANOVA, p<0.05) in SGRw in the fourth measurement. Group $2 A B C$ has a significantly higher SGRw $\left(5.0064 \%\right.$ day $\left.^{-1} \pm 0.05394\right)$ than group $1 A B C$ (4.7711\%day $\left.{ }^{-1} \pm 0.01715\right)$. This leads to the conclusion that in the second group $2 A B C$, the backlog of 4 days in mass was compensated. It is also noted that mortality in the first group $(1 A B C)$ was only $1 \%$, while in the second group $(2 A B C)$ it was $3.7 \%$. Consequently, a higher density of the fry in the first group $(1 A B C)$ could have an impact on a lower growth rate.

How to Cite
Kurtela, A. (2021): Impact of the duration of larval yolk sac absorption on the development of rainbow trout Oncorhynchus mykiss (Walbaum 1792) fry. Croatian Journal of Fisheries, 79, 119-123. DOI: 10.2478/cjf-2021-0013. 


\section{INTRODUCTION}

Rainbow trout Oncorhynchus mykiss (Walbaum 1792) is one of the most important fish species in aquaculture and sport fishing in the world because of ease of breeding and market value (Aganović, 1979). According to FAO data (FAO, 2018), rainbow trout Oncorhynchus mykiss is the second most cultured coldwater fish species in the world, contributing $2 \%$ (0.8 million tons) to the world's total finfish aquaculture production. Breeding technology is constantly being improved by various methods in order to achieve a larger number of fish with the best possible growth. Many factors affect fish production and with the advancement of technology more and more research has been conducted on how to improve breeding, based on improving good breeding characteristics and eliminating less favorable ones. In this paper, the development of rainbow trout fry was investigated. Although spawning took place on the same day, not all larvae absorbed the yolk sac at the same time, and this difference can be up to a week. The length of the incubation period, as well as the development of the embryo, depends on several factors. The first factor is water temperature, followed by the intensity of light, the flow of water per unit time, available dissolved oxygen in the water, and finally the age of the female and their hereditary characteristics (Aganović, 1979). Larvae of rainbow trout that first absorbed the yolk sac begun to actively feed earlier, while those that absorbed the yolk sac for a longer period begun active feeding later, leading to the assumption that this may affect future development of the fry. The aim of this study was to measure the mass increase of rainbow trout fry and to determine whether there are differences in the weight of the fry from the same broodstock, fertilized on the same day but with different yolk sac absorption periods.

\section{MATERIALS AND METHODS}

The experiment was conducted at Pšata Fish Farm $\left(46^{\circ} 23^{\prime}\right.$ N, $14^{\circ} 53^{\prime} \mathrm{E}$, Cerkelje na Gorenjskem, Slovenia), which is located at the spring of the Pšata stream. The fish farm is spawning and raising rainbow trout Oncorhynchus mykiss. In the period when there are not enough eggs, or under the unfavorable conditions for spawning, fertilized eggs are imported from other countries. Rainbow trout eggs, in the eye phase, were delivered in plastic transport boxes from Denmark on 17 March 2017. The eggs were placed in longitudinal incubators at a constant water temperature of $10^{\circ} \mathrm{C}$ and a water flow of $0.5 \mathrm{l} / \mathrm{s}$. On 23 March 2017, the first hatching of larvae began and three days later, on 26 March 2017, all the larvae hatched. In the next stage, larvae fed on the yolk sac and remained at the bottom of the incubators. On 10 April 2017, the separation of the fry which first started active feeding was done in three replicas of 100 individuals each (1A,
$1 \mathrm{~B}$ and $1 \mathrm{C})$. Likewise, the last fry that started the active phase were also separated into three replicas of 100 individuals (2A, 2B and 2C) on 14 April 2017. The replicas were transferred into new incubators, $0.4 \times 0.4 \mathrm{~m}$ with $0.2 \mathrm{~m}$ water depth. Both fry groups were kept in equal living conditions. Feeding was done manually with Biomar fish feed with a granulation of $0.5 \mathrm{~mm}, 5-6$ times a day ad libitum. As the fish grew, the granulation increased and the number of feedings per day decreased. Daily records of mortality were kept. Four individual weighings of 20 randomly selected fry from each replicate batch (1A, 1B, $1 C, 2 A, 2 B, 2 C)$ were performed. The first measurement was on 16 May 2017. At that time the fry from groups $1 A B C$ were 36 days into the active feeding phase and the ones from groups $2 A B C$ were 32 days into the active feeding phase, respectively. The second measurement was performed four days later, on 20 May 2017, in order to compare weights of both groups of the fry after the same period since active feeding began, with fry 40 days $(1 A B C)$ and 36 days $(2 A B C)$ into the active feeding phase, respectively. The third weight measurement was performed on 25 June 2017 when the fry (1ABC) was into the active feeding phase, 76 days and ( $2 A B C) 72$ days, respectively. The fourth measurement was done 4 days after, on 29 June 2017, with the fry at $80(1 A B C)$ and $(2 A B C) 76$ days into the active feeding phase, respectively. A precision electronic scale, Exacta $300 \mathrm{~EB}$, was used to measure weight to the nearest $\mathrm{mg}$. In order to measure weight as accurately as possible, the fry was subjected to anesthesia. The body weight of the fry was analyzed (ind. BW $\pm S D$, min., max. with $95 \%$ confidence interval). The specific growth rate for weight (SGRw) for each group $(1 A B C$ and $2 A B C)$ was also calculated using the formula:

$$
\operatorname{SGRw}(\%)=(\mathrm{SGRW})=[\ln \mathrm{W} 1-\ln \mathrm{W} 2 \times \mathrm{t} 1-\mathrm{t} 0-1] \times 100
$$

where:

In W1 - natural logarithm of the weight at time t1, In W2 - natural logarithm of the initial weight at time t0 Initial weight was used as $0.1 \mathrm{~g}$, after the average weight of larvae that absorbed the yolk sac and started active feeding (Aganović, 1979). The body weight of replicate groups and SGRw data were analysed with one way ANOVA $(p<0.05)$. Statistical analysis was performed in Microsoft Excel.

\section{RESULTS}

ANOVA analysis of replicates showed $(p>0.05)$ that there were no statistical differences between the batches $1 \mathrm{~A}$, $1 B, 1 C$ and the batches $2 A, 2 B, 2 C$, so in further work these are called groups $1 A B C$ and group $2 A B C$. It has also been determined that the fry that first absorbed the yolk sac had only $1 \%$ mortality $(1 A B C)$, while those that absorbed the yolk sac 4 days later ( $2 A B C$ ) had a higher mortality rate of $3.7 \%$. Table 1 shows basic statistical data for all body weight measurements by groups $1 \mathrm{ABC}$ and $2 \mathrm{ABC}$. 
Table 1. Basic statistical data for all body weight $(\mathrm{g})$ measurements by groups $1 \mathrm{ABC}$ and $2 \mathrm{ABC}$

\begin{tabular}{ccc|cc|cc|cc}
\hline & \multicolumn{2}{c|}{ 1. MEASUREMENT } & \multicolumn{2}{c|}{ 2. MEASUREMENT } & \multicolumn{2}{c|}{ 3. MEASUREMENT } & \multicolumn{2}{c}{ 4. MEASUREMENT } \\
\cline { 2 - 9 } & 1ABC & 2ABC & 1ABC & 2ABC & 1ABC & 2ABC & 1ABC & 2ABC \\
\hline Ind. BW & 0.7078 & 0.6704 & 0.8711 & 0.7918 & 4.4718 & 4.0714 & 4.6809 & 4.5761 \\
SD & 0.12106 & 0.10874 & 0.12897 & 0.13627 & 0.96661 & 1.02966 & 1.08334 & 0.86185 \\
& 0.6765 & 0.6423 & 0.8378 & 0.7566 & 4.222 & 3.8054 & 4.4011 & 4.3535 \\
$95 \%$ & 0.7391 & 0.6985 & 0.9044 & 0.827 & 4.7215 & 4.3374 & 4.9608 & 4.7988 \\
MIN & 0.46 & 0.27 & 0.62 & 0.49 & 2.22 & 2.19 & 1.65 & 2.37 \\
MAX & 0.97 & 0.86 & 1.2 & 1.05 & 6.09 & 7.74 & 7.89 & 6.48 \\
\hline \hline
\end{tabular}

The first measurement showed that the average weight of individuals of the first group $(1 A B C)$ was $0.7078 \pm 0.120106$ $\mathrm{g}$, and of the second group $(2 \mathrm{ABC}) 0.6704 \pm 0.10874 \mathrm{~g}$, which proves that the fry that started active feeding four days earlier were more advanced in weight than those that started active feeding later. On the second measurement, the average weight of individuals of the first group (1ABC) was $0.8711 \pm 0.12897 \mathrm{~g}$, while the average weight of the second group $(2 \mathrm{ABC})$ was $0.7918 \pm 0.13627 \mathrm{~g}$. Comparing the average individual weight of the first $(A B C)$ and the second group $(2 A B C)$, when the fry is equal number of days from the beginning of active feeding (36 days), it was found that the group $1 \mathrm{ABC}$ average individual weight was lower at $0.7078 \pm 0.120106 \mathrm{~g}$ than group $2 A B C$ with $0.7918 \pm 0.13627 \mathrm{~g}$. On the third measurement, the average weight in the first group $(1 A B C)$ was $4.4718 \pm 0.96661 \mathrm{~g}$, and in the second group ( $2 A B C$ ) it was $4.0714 \pm 1.02966 \mathrm{~g}$. Four days later, on the last measurement, the total average weight in the first group $(1 \mathrm{ABC})$ was $4.6809 \pm 1.08334 \mathrm{~g}$, and in the second group $(2 \mathrm{ABC})$ it was $4.5761 \pm 0.86185 \mathrm{~g}$.
When comparing groups with the same number of days from the beginning of the active phase (76 days), when the average weight of group $1 A B C$ was $4.4718 \pm 0.96661$ $\mathrm{g}$ and the average individual weight of group $2 A B C$ was $4.5761 \pm 0.86185$ grams, it was found that the average individual weight of the fry in group $2 A B C$ is again higher than in group $1 A B C$.

The specific growth rate in weight (SGRw) was calculated for each group ( $1 A B C$ and $2 A B C$ ) for all four measurements (Table 2). The last measurement on 29 June 2017 shows there is no statistically significant difference (one-way ANOVA, $p>0.05$ ) in SGRw between groups $1 A B C$ and $2 A B C$ in the first three measurements, whereas for SGRw there is a statistically significant difference (one-way ANOVA, $\mathrm{p}<0.05$ ) and group $2 A B C$ has significantly higher SGRw (5.0064\%day-1 \pm 0.05394$)$ than group $1 A B C$ (4.7711\%day$1 \pm 0.01715)$. It was also found that all fry initially grow faster (SGR is higher in the first measurements) and later the growth slows down.

Table 2. Statistical calculation of SGRw as a percentage per day

\begin{tabular}{|c|c|c|c|c|c|c|c|}
\hline \multicolumn{8}{|c|}{ SGRw $\left(\%\right.$ day $\left.^{-1}\right)$} \\
\hline \multicolumn{2}{|c|}{ 1. MEASUREMENT } & \multicolumn{2}{|c|}{ 2. MEASUREMENT } & \multicolumn{2}{|c|}{ 3. MEASUREMENT } & \multicolumn{2}{|c|}{ 4. MEASUREMENT } \\
\hline $1 \mathrm{ABC}$ & $2 A B C$ & $1 \mathrm{ABC}$ & $2 A B C$ & $1 \mathrm{ABC}$ & $2 A B C$ & $1 \mathrm{ABC}$ & $2 A B C$ \\
\hline 5.436 & 5.946 & 5.550 & 5.912 & 5.001 & 5.148 & 4.771 & 5.006 \\
\hline
\end{tabular}




\section{DISCUSSION}

In this study, there was no data on the size and age of the female fish from which the eggs had originated, and it is known that older and larger females lay larger eggs (Aganović, 1979). It is also unknown which eggs are from which female, since the eggs were mixed upon delivery. Therefore there was no possibility to monitor the development of the eggs from the very beginning. Besides, no measurement of the size of the egg diameter was performed and some authors claim that larger larvae hatch from larger eggs but that larvae from smaller eggs absorb the yolk sac faster (Escaffre and Bergot, 1984). Our basic assumption was that those young that started active feeding earlier will have an advantage in development and weight over those that consumed the yolk sac for a longer period and started active feeding later. Apart from egg size, yolk utilization and larval development are under the control of some environmental variables such as temperature, oxygen level, salinity and light (Çalta, 2001). Yolk utilization and larval growth declined with decreasing temperature in Oncorhynchus mykiss (Kamler and Kato, 1983). Segers et al. (2012) argue that large eggs usually mean greater survival of offspring, but females must compensate egg size for egg abundance. Females often produce smaller eggs when environmental conditions are favorable for the offspring, which is later compensated with the accelerated growth of the young. Others argue that no significant difference has been shown in the growth of fish hatched from eggs of different sizes (From and Rasmussen, 1991). Valdimarsson et al. (2002) discuss attributes related to external feeding, such as digestive and sensory systems, and hypothesize that these characteristics should develop relatively early in smaller embryos because of limited nutrients in the yolk, and the prospect of having to rely to a great extent on external energy for the development of other features. Body size in larvae has been reported to be positively related to resistance on starvation (Marsh, 1986; Miller et al., 1988). Size differences in larvae, but not female parent size, was positively related to egg size (Beacham and Murray, 1985; Baroudy and Elliott, 1994).

\section{CONCLUSION}

By monitoring the growth and development of rainbow trout Oncorhynchus mykiss fry in four measurements over 80 days from the beginning of active feeding of the first fry group $(1 A B C)$ and 76 days from the beginning of the active phase of the second fry group $(2 A B C)$, it was found that the weight of the first group $(1 A B C)$ was always higher than the second $(2 A B C)$, considering average individual body weight by measurements. However, when comparing the weight of both groups for the same number of days from the beginning of active feeding, it was noticed that the second group $(2 A B C)$ had a higher average individual weight than the first group ( $1 A B C)$. There was a statistically significant difference in the fourth measurement where group $2 A B C$ had a significantly higher SGRw than group $1 A B C$. This means that fry in the second group $2 A B C$ compensated the mass lag of 4 days, which submits our basic assumption that those young that started active feeding earlier will have an advantage in development and weight over those that consumed the yolk sac for a longer period and started active feeding later. The first group $(1 A B C)$ was found to be more resistant in mortality than the second group ( $2 A B C)$, leading to the conclusion that the higher stocking density in the first group (1ABC) could have an impact on a lower growth rate. The aim of this research is to improve breeding protocols in rainbow trout and other commercially important species. This work can also serve as a tool for future reference, where mass and SGRw can be tracked until the market size of fish.

\section{ACKNOWLEDGMENTS}

I would like to thank Prof. Tomislav Treer, PhD who introduced me to the good people from Slovenia, encouraged me to work and was always there when I needed help, and to Prof. Daniel Matulić, PhD for helping me with statistical analysis. Also, special thanks to recently deceased Prof. Jurij Pohar, PhD from the University of Ljubljana, Slovenia who gave me the idea for this work, and Mr Janez Vidmar and Mr Leon Sršen from Pšata fish farm for providing technical assistance. I am grateful to Nikša Glavić, PhD for editing this work by improving the English language and giving expert advice.

\section{UTJECAJ VREMENA APSORPCIJE ŽUMANJČANE VREĆICE LARVI NA RAZVOJ MLAĐI KALIFORNI- JSKE PASTRVE Oncorhynchus mykiss (WAL- BAUM, 1972)}

\section{SAŽETAK}

Ličinke Kalifornijske pastrve (Oncorhynchus mykiss, Walbaum, 1792) koje su prve započele sa aktivnom hranidbom izdvojene su u tri replikatne skupine $(1 \mathrm{~A}, 1 \mathrm{~B}, 1 \mathrm{C})$ po 100 jedinki, dok su ličinke koje su zadnje započele $s$ aktivnom hranidbom izdvojene četiri dana iza, te također raspoređene $\mathrm{u}$ tri replikatne skupine $(2 \mathrm{~A}, 2 \mathrm{~B}, 2 \mathrm{C})$ po 100 jedinki. Obavljena su četiri mjerenja, $s$ razmakom od četiri dana između prvog i drugog mjerenja, kao i između trećeg i četvrtog mjerenja, kako bi se usporedile inicijalne mase jedinki po grupama ( $1 A B C$ i $2 A B C$ ) na isti dan od početka aktivne hranidbe. Prosječna inicijalna masa mlađi je generalno veća kod prve skupine $(1 A B C)$ u sva četiri mjerenja. Ipak, kod usporedbe prosječne inicijalne mase kod obje grupe ( $1 A B C$ I $2 A B C$ ) na isti broj dana od početka aktivne hranidbe, grupa $2 A B C$ ima višu prosječnu inicijalnu 
masu od grupe $1 A B C$. Nije bilo statistički značajne razlike (ANOVA, p>0,05) između grupa kod SGRw-a u prva tri mjerenja, dok kod četvrtog mjerenja postoji statistički značajna razlika (ANOVA, $p<0,05$ ), te skupina $2 A B C$ ima veći SGRw (5.0064\%dan-1 \pm 0.05394$)$ od skupine $1 A B C$

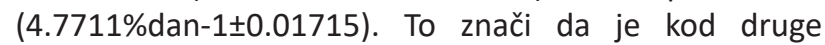
skupine $2 A B C$ nadoknađen zaostatak u masi od 4 dana. Ipak, uzima se u obzir da su uginuća kod prve skupine $(1 A B C)$ bila samo $1 \%$, dok su kod druge skupine (2ABC) $3.7 \%$, što može značiti da je veća gustoća nasada kod prve skupine (1ABC) mogla imati utjecaj na nižu stopu rasta.

Ključne riječi: riba, kalifornijska pastrva, težina, brzina rasta, SGRw

\section{REFERENCES}

Aganović M. (1979): Salmonidne vrste riba i njihov uzgoj. Igkro „Svjetlost“ OOUR zavod za udžbenike, Sarajevo.

Baroudy, E. and Elliott, J.M. (1994): Racial differences in eggs and juveniles of Windermere charr, Salvelinus alpinus. Journal of Fish Biology, 45, 407-415.

Beacham, T. D., Murray, C. B. (1985): Effect of female size, egg size, and water temperature on developmental biology of chum salmon (Oncorhynchus keta) from the Nitinat River, British Columbia. Canadian Journal of Fisheries and Aquatic Sciences, 42, 1755-1765.

Çalta, M. (2001): The Effect of Egg Size on Yolk Utilization and Growth of Rainbow Trout Alevins (Oncorhynchus mykiss Walbaum). Biologia future, 52, 117-123.
Escaffre A, Bergot P. (1984): Utilization of the yolk in rainbow trout alevins (Salmo gairdneri Richardson): effect of egg size. Reproduction, nutrition, development, 4, 449-460.

FAO, 2018. The State of World Fisheries and Aquaculture 2018, Meeting the Sustainable Development Goals. FAO, Rome. D.

From J., Rasmussen G. (1991): Growth of rainbow trout, Oncorhynchus mykiss (Walbaum, 1792) related to egg size and temperature, Dana. pp.3l-38.

Kamler, E., Kato, T. (1983): Efficiency of yolk utilization by Salmo gairdneri in relation to incubation temperature and egg size. Pol. Arch. Hydrobiol. 30, 271-306.

Marsh, E. (1986): Effects of egg size on offspring fitness and maternal fecundity in the orangethroat, Etheostoma spectabile (Pisces: Percidae). Copeia, 1986, 1830.

Miller, T. J., Crowder, L. B., Rice, J. A., Marchall, E. A. (1988): Larval size and recruitment mechanisms in fishes: toward a conceptual framework. Canadian Journal of Fisheries and Aquatic Sciences, 45, 1657-1670.

Segers F. H. I. D, Berishvili G., Taborsky B. (2012): Egg sizedependent expression of growth hormone receptor accompanies compensatory growth in fish. Proceedings of the royal society biological sciences, 592-600.

Valdimarsson S. K., Skulason S., Snorrason S. S. (2002): The relationship between egg size and the rate of early development in Arctic charr, Salvelinus alpinus. Environmental Biology of Fishes, 65, 463-468. 